\title{
Acute hemolytic crisis in a patient with hemoglobin constant spring disease: a case report
}

\author{
Wattana Insiripong ${ }^{1}$ and Somchai Insiripong ${ }^{2 *}$ \\ ${ }^{1}$ Medical Student, China Medical University, Shenyang, People's Republic of China \\ ${ }^{2}$ Maharat Nakhon Ratchasima Hospital, Nakhon Ratchasima, 30000, Thailand
}

\begin{abstract}
Hemoglobin Constant Spring (CS) is an abnormal alpha hemoglobinopathy with 172 amino acids. For Hb CS disease, the patients mostly have mild anemia with normocytosis. So far it is very unusual for $\mathrm{Hb}$ CS disease to present with acute hemolytic crisis during febrile illness. This paper was aimed to present a case of acute hemolytic crisis during having pneumonia that was later proved to harbor $\mathrm{Hb}$ CS disease. A 59-year-old Thai woman presented with fever, dry cough and pallor for 3 days. The physical examination revealed body temperature 38.5 degree Celsius, frank anemia and jaundice. The blood tests showed: $\mathrm{Hb}_{5.1} \mathrm{~g} \%$, WBC $18,540 / \mathrm{mm}^{3}$, platelet 193,000/mm $\mathrm{mm}^{3}$, MCV $82.3 \mathrm{fl}$, polychromasia $1+$, AST $25 \mathrm{U} / \mathrm{L}$, ALT $18 \mathrm{U} / \mathrm{L}$, direct bilirubin $1.8 \mathrm{mg} \%$, indirect bilirubin $13.5 \mathrm{mg} \%$, sputum C/S yielded $H$. parainfluenzae and $K$. pneumoniae, negative direct anti-globulin tests. The chest film was compatible with pneumonia. She responded well to antibiotics and blood transfusion. Four months later, her blood tests showed: Hb $10.5 \mathrm{~g} \%, \mathrm{MCV} 82.3 \mathrm{fl}, \mathrm{Hb}$ analysis: A, ACS, Hb CS 5.8\%, Hb A, 1.4\%, indirect bilirubin 4.8 mg\%. The alpha-thalassemia-1 (SEA and Thai deletions) was not found. She was finally diagnosed as Hb CS disease that was complicated by acute hemolytic crisis during pneumonia. Although there is no proper explanation why few Hb CS disease patients behave like Hb $\mathrm{H}$ disease patients, viz., having mild anemia at the steady state and sudden development of hemolytic crisis during fever, different genetic background of $\mathrm{Hb}$ CS is suspected to play role.
\end{abstract}

\section{Introduction}

Acute hemolytic crisis is characterized by the sudden drop of hemoglobin level with signs of red blood cell (RBC) destruction such as an increased indirect bilirubinemia and signs of compensated RBC production such as an increased polychromasia. The destruction is more rapid than the production [1]. It can complicate any chronic hemolytic anemia particularly $\mathrm{Hb} \mathrm{H}$ disease if the patients expose to oxidation, for instance, the high fever from an infection [2].

Hemoglobin Constant Spring ( $\mathrm{Hb} \mathrm{CS}$ ) is the abnormally elongated alpha globin chain variant derived from the point mutation of the termination codon, the substitution of TAA with CAA. So, 141 amino acid polypeptide of alpha globin chain was added with 31 amino acid residues. In the homozygous forms, the patients mostly have mild hemolytic anemia with normal MCV and mild splenomegaly in some cases [3], Hb 11.5 g\%, MCV $87 \mathrm{fl}, \mathrm{MCH} 26.3$ pg, reticulocyte $11.5 \%$ with marked basophilic stippling, no free haptoglobin. And the $\mathrm{Hb}$ analysis consisted of $\mathrm{Hb} \mathrm{CS} 6.8 \%, \mathrm{Hb} \mathrm{A}_{2} 1.4 \%, \mathrm{Hb}$ Bart $1.5 \%$ and the rest was $\mathrm{Hb} \mathrm{A} \mathrm{[4].} \mathrm{The} \mathrm{acute} \mathrm{hemolytic} \mathrm{crisis} \mathrm{has} \mathrm{been} \mathrm{the} \mathrm{very} \mathrm{rare}$ complication in $\mathrm{Hb}$ CS disease even in the areas of high prevalence of $\mathrm{Hb}$ CS such as Thailand [5] or Malaysia [6], Hb can drop from $10.7 \mathrm{~g} \%$ at the steady state to $5.0 \mathrm{~g} \%$ during the crisis from viral infection [6]. Herein we report an additional case of acute severe hemolytic crisis in the patient who was later proved to harbor $\mathrm{Hb}$ CS disease.

\section{Case report}

A 59-year-old Thai woman was admitted because of fever with dry cough, pallor and jaundice for 3 days. She had no blood loss or dark urine. The physical examination revealed BT 38.5 degree Celsius, P $114 / \mathrm{min}$, frank pallor and jaundice, no splenomegaly.

The blood tests included: Hb $5.1 \mathrm{~g} \%$, Hct 15.3\%, WBC 18,540/

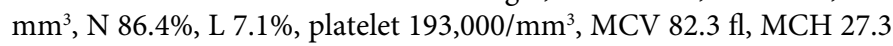

pg, MCHC 33.2 g\%, RDW 15.9\%, macrocyte 1+, polychromasia 1+, anisocytosis 1+, few microcyte, creatinine $0.84 \mathrm{mg} \%$, eGFR $76.8 \mathrm{ml} /$ min, albumin $3.9 \mathrm{~g} \%$, globulin $3.0 \mathrm{~g} \%$, AST $25 \mathrm{U} / \mathrm{L}$, ALT $18 \mathrm{U} / \mathrm{L}$, alkaline phosphatase $66 \mathrm{U} / \mathrm{L}$, direct bilirubin $1.8 \mathrm{mg} \%$, indirect bilirubin $13.5 \mathrm{mg} \%$, hs troponin-I 104.9 (normal <20 ng/L), CK-MB 0.8 (normal $<6.6 \mathrm{mg} / \mathrm{ml}$ ), sputum $\mathrm{C} / \mathrm{S}$ yielded numerous $H$. parainfluenzae and few $K$. pneumoniae, hemo $\mathrm{C} / \mathrm{S}$ yielded no growth, influenza test-negative, negative direct and indirect anti-globulin tests, and normal coagulation tests.

The chest film showed pulmonary infiltration at bilateral lower lobes, mild cardiomegaly. Impression: pneumonia and cardiomegaly. And the computerized tomography of the upper abdomen showed slight hepatomegaly, the gall bladder was operated due to symptomatic multiple gall stones when she was 55 years of age.

Six months before this admission: Hb 9.5 g\%, Hct 29.1\%, MCV $85.1 \mathrm{fl}, \mathrm{MCH} 27.8 \mathrm{pg}$, MCHC $32.6 \mathrm{~g} \%$, RDW 16.2\%, few anisocytosis, few poikilocytosis, $\mathrm{Hb}$ analysis by the high-performance liquid chromatography method: $\mathrm{A}_{2} \mathrm{ACS}, \mathrm{Hb} \mathrm{A}_{2} 1.3 \%$, Hb F $2.0 \%$

She was diagnosed as pneumonia and acute severe hemolytic crisis and treated with cefotaxime, azithromycin and oseltamivir. Five units of packed RBC were transfused to her. The fever gradually subsided and she could be discharged on the $3^{\text {rd }}$ day of admission.

Four months later, the blood was tested again, $\mathrm{Hb} 10.5 \mathrm{~g} \%$, Hct 35.4\%, WBC 8,660/mm³, MCV 82.3 fl, MCH 27.3 pg, RDW $15.9 \%$

Correspondence to: Somchai Insiripong, Maharat Nakhon Ratchasima Hospital, Nakhon Ratchasima, 30000, Thailand, Email: chaikorat@gmail.com

Key words: acute hemolytic crisis, Hb Constant Spring Disease

Received: July 09, 2017; Accepted: August 18, 2017; Published: August 21, 2017 
and $\mathrm{Hb}$ analysis by the capillary zone electrophoresis (CZE) method: $\mathrm{A}_{2} \mathrm{ACS}, \mathrm{Hb} \mathrm{CS} 5.8 \%, \mathrm{Hb} \mathrm{A}_{2} 1.4 \%, \mathrm{Hb} \mathrm{F} 1.8 \%$, the PCR for alpha thalassemia-1 was negative for SEA and Thai deletions, AST $24 \mathrm{U} / \mathrm{L}$, ALT $12 \mathrm{U} / \mathrm{L}$, total bilirubin $5.1 \mathrm{mg} \%$ indirect bilirubin $4.8 \mathrm{mg} \%$, and normal G-6-PD enzyme.

Her final diagnosis was $\mathrm{Hb}$ CS disease that experienced acute severe hemolytic crisis during having fever due to pneumonia.

\section{Discussion}

The diagnosis of $\mathrm{Hb}$ CS disease in our case was concluded based on the finding of $5.8 \%$ of $\mathrm{Hb} \mathrm{CS}$ on $\mathrm{Hb}$ analysis using the CZE method during the steady state because the percentage of $\mathrm{Hb}$ CS ranged 4.7$5.3 \%$ in $\mathrm{Hb}$ CS disease and $0.4-.0 .7 \%$ in $\mathrm{Hb}$ CS traits [6].

From mild anemia, our case develops acute severe anemia from hemolytic crisis during fever that looks closely similar to $\mathrm{Hb} \mathrm{H}$ disease patients when expose to fever [2]. Furthermore, $\mathrm{Hb}$ CS disease patients were found [7-9] mimicking $\mathrm{Hb} \mathrm{H}$ disease with [10] or without $\mathrm{Hb} \mathrm{CS}$ trait [11] as an unusual cause of a hydrops fetalis in utero.

$\mathrm{Hb}$ CS disease may be complicated by an autoimmune hemolytic anemia leading to the sudden drop of $\mathrm{Hb}$ level until the $\mathrm{Hb} \mathrm{CS}$ could be absent on $\mathrm{Hb}$ analysis [12] but the direct antiglobulin test was negative in our case. Other common causes of acute hemolytic crisis including G-6-PD deficiency and hereditary spherocytosis [13] could be excluded by the laboratory and morphology [14], respectively.

During hemolytic crisis, $\mathrm{Hb}$ level of a $\mathrm{Hb}$ CS disease patient could drop to $5.0 \mathrm{~g} \%$ from $10.7 \mathrm{~g} \%$ at the steady state [6]. Likewise, $\mathrm{Hb}$ was $5.1 \mathrm{~g} \%$ in our case during crisis and blood transfusion was in need and later it was maintained at $9.5-10.8 \mathrm{~g} \%$ without transfusion at the steady state.

There was no appropriate explanation why the minority of $\mathrm{Hb}$ CS disease patients has an unusual and potentially severe presentation as if they harbored $\mathrm{Hb} \mathrm{H}$ disease. In China, 9 patients with $\mathrm{Hb}$ CS disease were found to have different manifestations, 4 had no symptom, 2 had mild anemia and splenomegaly and 3 had jaundice but all of them had similarly hypochromia, aniso-poikilocytosis and target cells in the smear [15]. The study in Thailand found haplotypic heterogeneity of $\mathrm{Hb}$ CS among different ethnic background in Southeast Asia, and the differences of $\mathrm{Hb}$ concentration and the MCV depend on the different genetic combination between $\mathrm{Hb} \mathrm{CS}$ and other thalassemias and/or hemoglobinopathies [16].

\section{Conclusion}

A 59-year-old Thai woman with $\mathrm{Hb}$ Constant Spring disease developed acute severe hemolytic crisis during having pneumonia. $\mathrm{Hb}$ CS disease in our case seems to run the clinical course as if it were $\mathrm{Hb} \mathrm{H}$ disease.

\section{References}

1. Taher A, Vichinsky E, Musallam K, Cappellini MD, Viprakasit V (2013) Hemolytic Crisis. In: Weatherall D. Guidelines for the Management of Non-Transfusion Dependent Thalassaemia (NTDT). Nicosia, Cyprus: Thalassaemia International Federation. [Crossref]

2. Fucharoen S, Viprakasit V (2009) Hb H disease: clinical course and disease modifiers. Hematology Am Soc Hematol Educ Program: 26-34. [Crossref]

3. Pootrakul P, Winichagoon P, Fucharoen S, Pravatmuang P, Piankijagum A, et al. (1981) Homozygous haemoglobin Constant Spring: a need for revision of concept. Hum Genet 59: 250-255. [Crossref]

4. Derry S, Wood WG, Pippard M, Clegg JB, Weatherall DJ, et al. (1984) Hematologic and biosynthetic studies in homozygous hemoglobin Constant Spring. J Clin Invest 73: 1673-1682. [Crossref]

5. Viprakasit V, Veerakul G, Sanpakit K, Pongtanakul B, Chinchang W, et al. (2004) Acute haemolytic crisis in a Thai patient with homozygous haemoglobin Constant Spring ( $\mathrm{Hb}$ CS/CS): a case report. Ann Trop Paediatr 24: 323-328. [Crossref]

6. Azma R-Z, M-Gaus K, A-Aziz S, Alauddin H, Ithnin A, et al (2016). Detection of homozygous haemoglobin Constant Spring by capillary electrophoresis method. ARC J Hematol 1: 28-32.

7. Gallivan MVE, Vlastos EJ, Hanson RD, Bettinoti MP, Schonberg SA, et al (2009) Hemoglobin $\mathrm{H}$ hydrops fetalis associated with homozygous hemoglobin Constant Spring. Case report. Blood 2005 106: 3821, Am J Hematol 84: 759-61.

8. Charoenkwan P, Sirichotiyakul S, Chanprapaph P, Tongprasert F, Taweephol R, et al. (2006) Anemia and hydrops in a fetus with homozygous hemoglobin constant spring. $J$ Pediatr Hematol Oncol 28: 827-830. [Crossref]

9. He Y, Zhao Y, Lou JW, Liu YH, Li DZ (2016) Fetal Anemia and Hydrops Fetalis Associated with Homozygous Hb Constant Spring (HBA2: c.427T > C). Hemoglobin 40: 97-101. [Crossref]

10. He S, Zheng C, Meng D, Chen R, Zhang Q, et al. (2015) Hb H Hydrops Fetalis Syndrome Caused by Association of the - -(SEA) Deletion and $\mathrm{Hb}$ Constant Spring (HBA2: c.427T > C) Mutation in a Chinese Family. Hemoglobin 39: 216-219. [Crossref]

11. Lorey F, Charoenkwan P, Witkowska HE, Lafferty J, Patterson M, et al. (2001) Hb H hydrops foetalis syndrome: a case report and review of literature. Br J Haematol 115: 72-78. [Crossref]

12. Ghasemi A, Pedram M, Keikhae B, Galedari H_R (2012). Unusual presentation of a patient with hemoglobin Constant Spring and immune hemolytic anemia. Iranian $J$ Neonatol 3: 91-3.

13. Cihan MK, Gokce H, Oruc M, Olcay L (2012) Hemolytic crisis as the initial presentation of hereditary spherocytosis induced by parvovirus B19 and herpes virus infection in a patient with the thalassemia trait: A case report. Turk J Hematol 29: 425-6. [Crossref]

14. Barcellini W, Fattizzo B (2015) Clinical Applications of Hemolytic Markers in the Differential Diagnosis and Management of Hemolytic Anemia. Dis Markers 2015: 635670. [Crossref]

15. Chen P, Long GF, Lin WX, Li SQ (2004) [Homozygous hemoglobin constant spring in Guangxi province]. Zhonghua Xue Ye Xue Za Zhi 25: 205-208. [Crossref]

16. Jomou W, Fucharoen G, Sanchaisuriya K, Nguyen VH, Fucharoen S (2015) Hemoglobin Constant Spring among Southeast Asian Populations: haplotypic heterogeneities and phylogenetic analysis. PLoS One 10: e0145230. [Crossref]

Copyright: (C2017 Insiripong W. This is an open-access article distributed under the terms of the Creative Commons Attribution License, which permits unrestricted use, distribution, and reproduction in any medium, provided the original author and source are credited. 